\title{
LEGAL REGULATION OF ACTIVITIES RELATING TO THE CIRCULATION OF DRUGS, PSYCHOTROPIC SUBSTANCES, THEIR ANALOGS AND PRECURSORS IN THE TERRITORY OF UKRAINE
}

\section{Sokolenko O. L.}

\section{INTRODUCTION}

Activities related to the circulation of narcotic, psychotropic substances, their analogues and precursors in Ukraine are conducted in Ukraine, so it is necessary to get acquainted with certain features, namely - to find out what requirements at the legislative level certain types of activities in this field should meet.

According to item 10, $22 \mathrm{~h}$. 1 Art. 7 of the Law of Ukraine "On Licensing of Economic Activities" the following types of economic activity are subject to licensing:

1) manufacture of medicines, wholesale and retail trade of medicines, import of medicines (except for active pharmaceutical ingredients) - taking into account the specifics defined by the Law of Ukraine "On Medicines"2;

2) cultivation of plants included in Table I of the List of narcotic drugs, psychotropic substances and precursors ${ }^{3}$ approved by the Cabinet of Ministers of Ukraine, development, production, manufacture, storage, transportation, acquisition, sale, import to the territory of Ukraine, export from the territory of Ukraine, use, destruction of narcotic drugs, psychotropic substances and precursors included in the above List,

1 Закон України "Про ліцензування видів господарської діяльності" від 02.03.2015 № 222-VIII (у ред. від 05.07.2017). [Електронний ресурс]: Режим доступу: http://zakon2.rada.gov.ua/laws/show/222-19. (ст. 7).

2 Закон України "Про лікарські засоби” від 04.04.1996 № 123/96-ВР (у редакції від 19.06.2016): [Електронний ресурс]. - Режим доступу: http://zakon0.rada.gov.ua/laws/show/123/ 96-вр.

${ }^{3}$ Невеликі, великі та особливо великі розміри наркотичних засобів, що знаходяться у незаконному обігу/Таблиця 1/ Затверджена наказом Міністерства охорони здоров'я України 01.08.2000 N 188 (у редакції 19.06.2015): [Електронний ресурс]. - Режим доступу: http://zakon2.rada.gov.ua/laws/show/z0512-00. 
taking into account the features defined by the Law of Ukraine "On Narcotic Drugs, Psychotropic Substances and Precursors ${ }^{4}$.

\section{Procedure for issuing a permit for the use of objects and premises, removal from Ukraine of funds intended for activities related to drug trafficking}

Licensing is conducted by a specially licensed licensing body and an expert-licensing board.

The license applicant submits to the licensing authority an application for a license under the defined license conditions form.

The licensing authority shall, within three working days of receipt of the license application, establish the existence or absence of grounds for leaving it without consideration and, if so, make the appropriate decision. The term for making a decision on the issue of a license is ten working days from the date of receipt by the subject of licensing of the license application. The acquisition by the licensee of the right to pursue the type of economic activity subject to licensing takes place from the moment of the decision of the licensing authority to issue the license to the Unified State Register of Legal Entities, Individual Entrepreneurs and Public Formations. In the decision to grant a license, the licensing authority specifies the payment details for the payment of the license. The license for conducting by the licensee of a certain type of economic activity subject to licensing shall be formalized by the licensing authority in electronic form (record of the decision of the licensing authority to issue a license to the entity in the Unified State Register of legal entities, natural persons - entrepreneurs and public entities) is displayed on the extract from the Unified State Register of Legal Entities, Entrepreneurs and Public Formations, which is issued to the licensee free of charge and is subject to obligatory compulsory disclosure of a portal for e-services in the manner prescribed by the Ministry of Justice of Ukraine in accordance provide information from the Unified State Register of Legal Entities and individuals - entrepreneurs and community groups. The license is issued for an unlimited period.

One-time minimum subsistence payment shall be charged for the issue of a license, based on the subsistence minimum for able-bodied persons, effective on the day the licensing authority makes a decision to

4 Закон України “Про наркотичні засоби, психотропні речовини і прекурсори” від 15.02.1995№ 60/95-ВР (у редакції 28.12.2015): [Електронний ресурс]. - Режим доступу: http://zakon2.rada.gov.ua/laws/show/60/95-вр. 
issue a license, unless another amount of payment is established by law. The license fee issued by the Council of Ministers of the Autonomous Republic of Crimea or a local executive body is 10 percent of the subsistence level for able-bodied persons effective on the day the license is issued. License renewal is free of charge.

For conducting licensed economic activity without a license or performing such economic activities in violation of licensing conditions, the officials of economic entities bear the administrative responsibility provided for by the Code of Administrative Offenses ${ }^{5}$.

In the absence of licensing conditions for conducting an appropriate type of economic activity subject to licensing under the law, the responsibility for conducting such economic activities without a license shall not apply.

Officials of the licensing authority bear administrative, material or disciplinary responsibility for violation of the legislation in the sphere of licensing.

According to the resolution of the CMU "Some Issues of Issuance of Permit for the Use of Objects and Premises for the Purpose of Activities Related to the Circulation of Narcotic Drugs, Psychotropic Substances and Precursors" of April 13, 2011, No. $469^{6}$ Authorization for the Use of Objects and Premises, intended for carrying out activities related to the circulation of drugs, psychotropic substances and precursors is issued to a legal entity by the head offices of the National Police in the Autonomous Republic of Crimea and the city of Sevastopol, the regions and the city of Kiev and according to the location of a legal entity, and in cases where activities related to narcotic drugs, psychotropic substances and precursors, shall not at the location of a legal entity - at the place of such activities ${ }^{7}$.

5 Кодекс України про адміністративні правопорушення (статті 1-212-21) від 07.12.1984 № 8073-Х (у редакції 16.04.2017): [Електронний ресурс]. - Режим доступу: http://zakon2.rada.gov.ua/laws/show/80731-10;

6 Постанова Кабінету Міністрів України “Деякі питання видачі дозволу на використання об'єктів і приміщень, призначених для провадження діяльності, пов'язаної з обігом наркотичних засобів, психотропних речовин і прекурсорів” від 13.04.2011 № 469 (у ред. від 11.04.2017). [Електронний ресурс]: Режим доступу: http://zakon2.rada.gov.ua/ laws/show/469-2011-п. ст. 2-17.

7 Закон України "Про Національну поліцію” від 2.07.2015p. № 580-19 (в ред. від 12.07.2017 р.). [Електронний ресурс]: Режим доступу: http://zakon2.rada.gov.ua/laws/show/ 580-19/page 
Permission is granted based on the results of the compliance check facilities and premises established by the Ministry of Internal Affairs requirements.

To obtain a permit, the legal entity submits in person or through an authorized body or person to a public administrator or a representative of a structural unit of a territorial authority National Police on Drugs Crime Statement for the form approved by the resolution of the Cabinet of Ministers of Ukraine dated 7.

December 2005 No.1176 "On Approval of the Form of Application for Obtaining by a Business Entity or Authorized Documents of a Permit Character" ${ }^{\prime \prime}$ to which accompanying documents are attached.

Legal entity whose activities are related to cultivation, transportation, storage and destruction of plants included in table I of the list, in addition to those specified in paragraph 4 of this Order of Documents, shall also submit copies:

- a document confirming the right at the time of application ownership of a land plot or permanent use or lease of a land plot;

- a document confirming the fact of purchase from the subjects of seed and nursery, entered in the State Register of producers of seeds and planting material, seeds for cultivation of plants included in the list (for poppy - the first reproduction, for hemp - the first or second reproduction);

- extraction from the map-scheme of the land plot with indication of the area of sowing, distance to settlements, forest lands, railways and highways of local importance;

- the agreement on the protection of the places of cultivation, storage and destruction of plants included in the list No. 3 of table I of the list, their crop residues and an annex, which specifies information on the location of forces and means of protection units.

In the case of transportation of parts of plants included in list N 3 of table $\mathrm{I}^{9}$ of the list, or their seeds, which do not meet the requirements of GOST 12094-76 or GOST 9158-76 as a percentage of trash, or their crop

8 Постанова Кабінету Міністрів України “Про затвердження форми заяви на одержання суб'єктом господарювання або уповноваженою ним собою документів дозвільного характеру” від 7.12.2005 р. N 1176 (в ред. від 11.02.2015 - втратив силу). [Електронний ресурс]: Режим доступу: http://zakon2.rada.gov.ua/laws/show/ru/1176-2005-п.

${ }^{9}$ Невеликі, великі та особливо великі розміри наркотичних засобів, що знаходяться у незаконному обігу / Таблиця 1 / Затверджена наказом Міністерства охорони здоров'я України 01.08.2000 N 188 (у редакції 19.06.2015): [Електронний ресурс]. - Режим доступу: http://zakon2.rada.gov.ua/laws/show/z0512-00. 
residues for further processing (purification), except These documents shall also include a copy of the contract for the protection of such parts of plants and seeds during carriage and the scheme of the carriage route.

Copies of documents are certified in due course. The application, submitted to the structural unit of the territorial authority of the National Police for the Fight against Drugs, is registered in the register of applications for permission to use the facilities or premises in the form approved by the Ministry of Internal Affairs.

In case of submission of the application to the state administrator and documents, he submits the following statement and documents to the structural unit of the territorial authority of the National Police on the fight against drug crime on the day of their submission or during the next business day, the statement registered.

For the purpose of checking the conformity of objects or premises established by the Ministry of Internal Affairs requirements are inspected by employees' structural subdivision of the territorial authority of the National the Police on Drugs and Police protection in the Autonomous Republic of Crimea and Sevastopol, regions and Kyiv. Objects or premises are inspected on time, which does not exceed three business days from the date of submission of the structural a subdivision of a territorial body of the National Police combating drug crime by a legal entity or a state the administrator of the application and documents. Inspection of objects or premises is carried out in the presence of representatives of the legal entity. According to the results of the inspection of the objects or premises, the survey acts are prepared according to the forms approved by the Ministry of Internal Affairs in agreement with the Ministry of Health, which states the possibility or impossibility of using the objects or premises for the activity related to the circulation of narcotic drugs, psychotropic substances and precursors.

Inspection acts are drawn up in duplicate and signed by employees of the structural unit of the territorial body of the National Police on Drugs and the Police in the Autonomous Republic of Crimea and Sevastopol, regions and Kyiv, a legal entity or an authorized national and territorial entity police. One copy of the survey act shall be issued to the legal entity or its authorized person, which shall be entered register of the acts of inspection of objects and premises, which shall be kept in the form approved by the Ministry of Internal Affairs in agreement with the Ministry of Health, and the second shall be kept in the relevant case of the territorial subdivision drug police. 
Decision to grant or refuse to grant it is accepted within 10 calendar days from the date of submission of the application and documents.

The legal person shall be issued a permit within three calendar days from the date of making the respective decision or a written notice of refusal of its issuance shall be given, stating the reasons for the refusal.

A permit or a written notice of refusal to issue a permit shall be issued in two copies, each of which shall be certified by the signature of the head of the territorial authority of the National Police, and in the absence thereof - by the deputy head or the person performing his duties, and shall be affixed with the seal of such authority.

The structural subdivision of the territorial authority of the National Police for the Suppression of Drug Crime issues one copy of the permit to the head of the legal entity or his representative in the presence of a duly issued power of attorney for obtaining a permit and a document certifying the identity, or to the state administrator for the transfer of the authorization to the legal entity in the order.

The permit of the structural unit of the territorial body of the National Police for Combating Drug Crime makes a note in the log of applications for obtaining permission for the use of objects or premises. The second copy of the permit, together with the documents, remains in the structural subdivision of the territorial authority of the National Police for the Suppression of Drug Crime and remains for the whole period of validity of the license for conducting activities related to the circulation of narcotic drugs, psychotropic substances and precursors, and for three years after the expiration of the term its actions. Permission is not allowed to be mailed. The period of validity of a permit may not exceed the period of validity of a license to engage in activities related to the circulation of narcotic drugs, psychotropic substances and precursors.

In case of refusal of the permit, the legal person has the right to apply again to the structural subdivision of the territorial body of the National Police for the fight against drug crime only on condition of elimination of the reasons which gave rise to the refusal. The decision to refuse the permit may be appealed in accordance with the procedure established by law.

Issuance of permits for the right to import into the territory of Ukraine the export of narcotic drugs, psychotropic substances and precursors from the territory of Ukraine by enterprises, institutions and organizations if they have licenses to carry out relevant activities in the sphere of narcotic drugs, psychotropic substances and precursors 
circulation, as well as the procedure for issuance permits for the right to transit narcotic drugs, psychotropic substances and precursors through the territory of Ukraine are determined in the order of issuing permits for the right to import into the territory of Ukraine, export from Ukraine or transit through the territory of Ukraine of narcotics, psychotropic substances and precursors approved by CMU from 02.03.1997 ${ }^{10}$.

Imports and exports of drugs, psychotropic substances and precursors are carried out by enterprises, subject to obtaining a permit for each individual operation issued by the State Service. The permit is issued in agreement with the SBU. Issuance (refusal of issue, reregistration, issue of duplicate, cancellation) of the permit is carried out in accordance with the Law of Ukraine "On the Permitting System in the Field of Economic Activity ${ }^{11}$,.

To obtain a permit for import into Ukraine for registration in the Ministry of Health of samples of narcotic drugs, psychotropic substances and precursors included in the list of controlled substances, in the form of medicines, as well as medicinal products, which include the controlled substances included in the list, the enterprise submits such documents :

1) statement on the letterhead of the enterprise addressed to the Head of the State Service, stating:

- the purpose with which the importation is made;

- full names, exact addresses, phone numbers (faxes) of the enterprise - importer (consignee);

- the international non-proprietary name of the imported product, if any, and (or) the first name under which it was issued and (or) the name under which it is produced in the importing country;

- quantity of narcotic drugs, psychotropic substances and precursors included in the list of controlled substances imported;

- the number of medicines that include controlled substances included in the list;

10 Постанова Кабінету Міністрів України “Порядок видачі дозволів на право ввезення на територію України, вивезення з території України або транзиту через територію України наркотичних засобів, психотропних речовин i прекурсорів" від 03.02.1997 № 146. [Електронний ресурс]: Режим доступу: http://zakon2.rada.gov.ua/ laws/show/146-97-п.

11 Закон України "Про дозвільну систему у сфері господарської діяльності" від 06.09.2005 № 2806-IV (у ред. від 05.07.2017). [Електронний ресурс]: Режим доступу: http://zakon2.rada.gov.ua/laws/show/2806-15. 
- dosage form of narcotic drugs, psychotropic substances, precursors and medicines, which include controlled substances included in the list;

- type of transport for delivery;

- delivery time;

- the name of the crossing point on the state border of Ukraine through which the importation will be made;

2) a letter of request from the Ministry of Health confirming the need to import a specified number of samples of drugs, psychotropic substances and precursors, included in the list of controlled substances, in the form of drugs, as well as medicines, which include included controlled substances, for registration in Ukraine and the guarantee of their storage, indicating the name of the person responsible for it;

3 ) the undertaking of the importing company to use narcotic drugs, psychotropic substances, precursors and medicines only for the stated purposes.

4) quality certificates for imported medicinal products.

To obtain a permit for the importation as a humanitarian aid of narcotic drugs, psychotropic substances and precursors included in the list of controlled substances in the form of medicinal products, as well as medicinal products that include controlled substances included in the list, an enterprise authorized to carry out activities in the sphere of circulation of these substances, submits the following documents:

1) a statement on the letterhead of the enterprise addressed to the Head of the State Service, stating:

- purpose for which importation is carried out:

- full names, addresses and telephone numbers of the exporter, the importer (consignee) company and the exporter;

- the international non-proprietary name of the imported product, if any, and (or) the first name under which it was issued and (or) the name under which it is produced in the importing and exporting countries;

- the amount of narcotic drugs, psychotropic substances and precursors included in the list of controlled substances in the form of medicinal products to be imported;

- the number of medicines that are included

controlled substances to be imported;

- dosage form of narcotic drug, psychotropic substance, precursor and drug;

- name of the manufacturer; 
- type of transport for delivery;

- delivery time;

- the name of the crossing point on the state border of Ukraine, through to be imported;

- the obligation of the enterprise to use humanitarian aid only on purpose and to inform the State Service within two months about its distribution;

2) the invoice, the freight declaration, the freight, customs, transport documents containing information on the amount of narcotic drugs, psychotropic substances, precursors and medicines, which include the controlled substances included in the list;

3 ) a notarized copy of the charter of the enterprise (consignee);

4) registration certificates for medicinal products imported into Ukraine (in the absence of such a certificate an act on the possibility of medical use of medicinal products is filed);

5) certificate of quality of narcotic drug or psychotropic substance with indication of expiration date (quality passport is added for precursors).

The import permit for narcotics, psychotropic substances and precursors shall specify:

- his registration number;

- name and address of the importer;

- name and address of the exporter;

- the name (including the international non-proprietary name) and the amount of narcotic drugs, psychotropic substances, precursors and drugs that include the controlled substances to be imported under the contract;

- name (including international non-proprietary name) and quantity

- narcotics, psychotropic substances and precursors included in the list of controlled substances to be imported under the contract;

- type of container and its quantity - for narcotic drugs, psychotropic substances and precursors in the form of a substance used for the manufacture of medicines;

- mode of transport;

- the name of the customs office and the name of the checkpoint at the state border of Ukraine, through which the importation and customs clearance of drugs, psychotropic substances, precursors and medicines will be carried out;

- date of issue;

- validity. 
The permit is signed by the head of the State Service and is affixed stamp of the State Service. To obtain a permit for export of narcotic drugs, psychotropic substances and recursors from Ukraine the following documents are submitted to the enterprise:

1) statement on the letterhead of the enterprise addressed to the Head of the State Service, stating:

- the purpose for which the export is carried out;

- full names, exact addresses, phone numbers (faxes) of the exporter, importer and consignee;

- the international non-proprietary name of the exported product, if any, and (or) the first name under which it was issued and (or) the name under which it is produced in the countries of export and import;

- name and quantity of narcotic drugs, psychotropic substances and precursors to be exported;

- dosage form of narcotic drug, psychotropic substance and precursor;

- name and quantity of narcotic drugs, psychotropic substances and precursors included in the list of controlled substances to be exported under the contract;

- name of the manufacturer:

- Delivery contract number;

- the cost of the delivery contract;

- name and number of packaging units for narcotic drugs, psychotropic substances and precursors in the form of a substance used for the manufacture of medicines;

- type of transport for delivery;

- delivery time;

- the name of the checkpoint at the state border of Ukraine through which the export will be made;

2) an invoice or pro forma invoice confirming information on the amount of drugs, psychotropic substances and precursors to be exported;

3) a notarized copy of the company's charter;

4) a notarized copy of the contract under which the export of narcotic drugs, psychotropic substances and precursors is carried out;

5) registration certificates for medicinal products exported from Ukraine; 
6) Certificate of quality of a narcotic drug, psychotropic substance or precursor included in the list No. 1 of table $\mathrm{IV}^{12}$, stating their expiration date, the manufacturer's quality passport or technical documentation showing the chemical composition of the product is added).

During the export of narcotic drugs, psychotropic substances and precursors included in List 4 of Table 4 of the controlled substances list, the exporter must, in each case, supply an import certificate (national certificate) issued by the competent authority of the importing country.

If there is no national certificate procedure in the importing country or guarantees are not provided, the counterpart of the importing country shall draw up an equivalent. The export of narcotic drugs, psychotropic substances and precursors by consignment to a prescriptive customs warehouse is prohibited, except where the government of the exporting country makes a mark on the placement of the imported consignment in the prescriptive customs warehouse.

In the permit for export of narcotic drugs, psychotropic substances and precursors are indicated:

- his registration number;

- name and address of the exporter;

- name and address of the importer;

- name (including international non-proprietary name) and quantity narcotic drugs, psychotropic substances and precursors and drugs, which include controlled substances;

- type of container and its quantity - for narcotic drugs, psychotropic substances and precursors in the form of a substance used for the manufacture of medicines;

- name (including international non-proprietary name) and quantity of narcotic drugs, psychotropic substances and precursors included in the List of controlled substances to be exported; issued;

- national import authorization number, date of issue, by whom

- mode of transport;

- the name of the customs office and the name of the border crossing point Ukraine through which export will be made;

- date of issue;

- validity.

12 Невеликі, великі та особливо великі розміри наркотичних засобів, що знаходяться у незаконному обігу / Таблиця 1 / Затверджена наказом Міністерства охорони здоров'я України 01.08.2000 N 188 (у редакції 19.06.2015): [Електронний pecypc]. - Режим доступу: http://zakon2.rada.gov.ua/laws/show/z0512-00. 
The permit is signed by the head of the State Service and is affixed stamp of the State Service. To obtain a permit for transit through the territory of the country of narcotic drugs, psychotropic substances and precursors the following documents are submitted to the enterprise:

1) statement on the letterhead of the enterprise addressed to the Head of the State Service, stating:

- full names, exact addresses, telephone and fax numbers of the exporter and importer;

- name and quantity of narcotic drugs, psychotropic substances and precursors to be transited;

- dosage form of narcotic drug, psychotropic substance and the precursor or the name of the product containing the precursors included in list No. 2 of table IV;

- Delivery contract number;

- type of transport for delivery;

- the name of the border crossing points through which the import and export will be carried out;

2) a copy of the contract certified by the company seals (if any) according to which the delivery is made;

3) Certificate of quality of narcotic drug, psychotropic substance or precursor included in the list No.1 of Table $\mathrm{IV}^{13}$, indicating their expiry date, the manufacturer's quality passport or technical documentation showing the chemical composition of the product is added.

The company must deliver in each case provide a certificate (national certificate) of the importing and exporting countries on exportimport operations. If there is no national certificate procedure in the importing country or guarantees are not provided, the counterpart of the importing country's authority shall draw up an equivalent.

\section{Regulation of the procedure for storage of narcotic drugs,} psychotropic substances and precursors removed from illicit trafficking.

Legislative provision of the order of transportation of narcotic drugs on the territory of Ukraine

Features of storage of narcotic drugs, psychotropic substances and precursors withdrawn from illicit trafficking are regulated by the

13 Невеликі, великі та особливо великі розміри наркотичних засобів, що знаходяться у незаконному обігу / Таблиця 1 / Затверджена наказом Міністерства охорони здоров'я України 01.08.2000 N 188 (у редакції 19.06.2015): [Електронний peсурс]. - Режим доступу: http://zakon2.rada.gov.ua/laws/show/z0512-00. 
procedure of storage of narcotic drugs, psychotropic substances and precursors withdrawn from illicit trafficking by the approved CMU resolution of May 7, 2008 No. $422^{14}$.

The storage of narcotics, psychotropic substances and precursors by the National Police, the Security Service of Ukraine and the State Customs Service is carried out without a corresponding license. For the storage of narcotic drugs, psychotropic substances and precursors, the National Police, the Security Service of Ukraine and the State Customs Service allocate premises that meet the requirements established by the Ministry of Internal Affairs. Permission to use the premises is not required. The head of the authority of the National Police, the Security Service of Ukraine and the State Customs Service appoints a person who is responsible for the storage and maintenance of narcotics, psychotropic substances and precursors.

The responsible person shall make an appropriate entry in the journal of the account of narcotic drugs, psychotropic substances and precursors, which is attached to the materials of criminal proceedings, about the taking for storage of narcotic drugs, psychotropic substances and precursors.

Drugs, psychotropic substances and precursors accepted for storage must be packed and sealed. Each package is affixed with a tag stating the accounting journal number and order number.

When taking drugs, psychotropic substances and precursors for storage, the responsible person checks the compliance of the data specified in the documents on the withdrawal and investigation of such drugs, substances and precursors with their actual status. Narcotic drugs, psychotropic substances and precursors, which cannot be stored in one room by volume, shall be transferred on the basis of a storage agreement concluded in accordance with the law to an entity holding a license.

The premises and the safes and metal cabinets in which narcotics, psychotropic substances and precursors are stored shall be sealed by the responsible person. Entrance to the premises is carried out in the presence of the responsible person. Drugs, psychotropic substances and precursors may be issued on the basis of a written reasoned request from an investigator, prosecutor, investigating judge or court conducting

14 Постанова Кабінету Міністрів України “Порядок перевезення наркотичних засобів, психотропних речовин і прекурсорів на території України та оформлення необхідних документів” від 17.04.2008 № 366 (у ред. від 18.03.2016). [Електронний pecyрс]: Режим доступу: http://zakon2.rada.gov.ua/laws/show/366-2008-п. 
criminal proceedings, as the responsible person makes an appropriate entry in the accounting log. Issued drugs, psychotropic substances and precursors are stored in a safe or metal cabinet.

The transportation of narcotics, psychotropic substances and precursors is carried out by the authorities of the National Police, the Security Service of Ukraine and the State Customs Service, provided their security and safety are ensured. The responsible person shall make an appropriate entry in the accounting log of the return of the indicated organs of drugs, psychotropic substances and precursors. The accounting $\log$ is laced and stamped by the authority, its pages are numbered. Records in the accounting log are made by the responsible person in the order of receipt of narcotics, psychotropic substances and precursors on the basis of documents on their withdrawal and research, which indicate the date of their receipt for storage, name, quantity, number of criminal proceedings, place of actual storage, as well as information on the dispensing of these agents, substances and precursors for the purposes prescribed by law.

Control over storage and accounting of narcotic drugs, psychotropic substances and precursors is carried out by a commission, which consists of the head of a body of the National Police, the Security Service of Ukraine and the State Customs Service, representatives of the unit responsible for record keeping, the expert-criminalistic unit and the unit on counter-narcotics, and precursors. The Commission shall review at least once a month the status and conditions of storage of narcotic drugs, psychotropic substances and precursors and the procedure for keeping them. As a result of the audit, an act is signed, signed by the members of the commission, transferred to the unit responsible for paperwork, and kept in the file. During the conduct of routine inspections of subordinate bodies by the authorities of the National Police, the Security Service of Ukraine and the State Customs Service, the state of storage and the procedure of keeping records of narcotics, psychotropic substances and precursors are compulsorily checked. In the case of improper storage and accounting of narcotics, psychotropic substances and precursors, an investigation is conducted.

Transportation of narcotic drugs across the territory of Ukraine is legally regulated and fixed in the order of transportation of narcotic drugs, psychotropic substances and precursors in the territory of Ukraine 
and registration of the necessary documents by the approved CMU resolution of April 17, 2008 No. $366^{15}$.

The transportation of drugs, psychotropic substances and precursors included in the list is carried out by economic entities on the basis of an appropriate license. Transportation of narcotic drugs, psychotropic substances and precursors, seized from the illegal traffic by the authorities of the National Police, SBU, State Border Guard Service and other units carrying out activities in accordance with the Law of Ukraine "On Operational and Investigative Activity" ${ }^{16 ", ~ a s ~ w e l l ~ a s ~ b y ~ t h e ~ S t a t e ~}$ Customs Service, within the limits of their powers and in the manner prescribed by the said authorities.

Transportation of narcotics, psychotropic substances and precursors is carried out by health care institutions, economic entities that carry out activities for their production, manufacture, as well as by road carriers, provided the cargo is safe. The transportation of these facilities, substances and precursors on the territory of Ukraine is carried out by road, air or water. The transport of narcotic drugs, psychotropic substances and precursors, with the exception of precursors included in list No. 2 of table $\mathrm{IV}^{17}$ of the list, is prohibited by rail and mail. Drugs, psychotropic substances and precursors are transported by motor vehicle, the technical condition of which meets the requirements of the Traffic Rules, approved by the Decree of the Cabinet of Ministers of Ukraine of October 10, 2001 No. $1306^{18}$, and the conditions of their safe transportation. The motor vehicle is completed, in addition to the equipment specified in the Road Traffic Rules, with a set of tools for minor repairs, a powder or carbon dioxide extinguisher with a capacity of not less than five liters and anti-recoil stops.

15 Постанова Кабінету Міністрів України “Порядок перевезення наркотичних засобів, психотропних речовин і прекурсорів на території України та оформлення необхідних документів” від 17.04.2008 № 366 (у ред. від 18.03.2016). [Електронний pecypc]. - Режим доступу: http://zakon2.rada.gov.ua/laws/show/366-2008-п.

16 Закон України "Про оперативно-розшукову діяльність" від 18.02.1992 № 2135-XII (у редакції 12.04.2017): [Електронний ресурс]. - Режим доступу: http://zakon3.rada.gov.ua/laws/show/2135-12.

17 Невеликі, великі та особливо великі розміри наркотичних засобів, що знаходяться у незаконному обігу/Таблиця 1/ Затверджена наказом Міністерства охорони здоров'я України 01.08.2000 N 188 (у редакції 19.06.2015): [Електронний ресурс]. Режим доступу: http://zakon2.rada.gov.ua/laws/show/z0512-00.

18 Постанова Кабінету Міністрів України "Правила дорожнього руху" від 10 жовтня 2001 р. № 1306 (у ред. від 05.04.2017). [Електронний ресурс]. - Режим доступу: http://zakon2.rada.gov.ua/laws/show/1306-2001-п. 
The transportation of narcotic drugs, psychotropic substances and precursors is carried out with the support of a responsible person appointed by the head of a health care institution or an economic entity that carries out activities for their production, manufacture. The fact of receipt of narcotic drugs, psychotropic substances and precursors is confirmed by a signed invoice signed by the responsible person stating the state number of the respective motor vehicle.

The transportation of these facilities, substances and precursors within the city or district shall be carried out without a permit issued by the National Police. The issue of cargo protection on the road is decided by the head of the health care institution or economic entity on the basis of specific circumstances. Transport of narcotic drugs, psychotropic substance of precursors, with the exception of precursors included in list IV of table IV of the list in the amount of 200 or more kilograms is carried out by a motor vehicle accompanied by a vehicle of special purpose patrol police or security police. The head of a healthcare facility or business entity is personally responsible for ensuring the safety of cargo and the confidentiality of transportation information.

The procedure for dispensing drugs, psychotropic substances and precursors, with the exception of precursors included in list No. 2 of table IV of the list, health care institutions and economic entities shall be established by the Ministry of Health. The leave for the transportation of precursors included in list No. 2 of table IV of the list is made by the person, determined by the order of the head of the health care institution or economic entity, who makes the release of such precursors, after acquaintance with it. The authorized person keeps a record of the precursors included in list No. 2 of table IV of the list, indicating in the special journal the total mass, the number of places, the destination, the number and the date of signing of the consignment note. The entry in the special journal shall be certified by the signature of the authorized person. During the leave (acceptance) for the transportation of narcotic drugs, psychotropic substances and precursors, the authorized person is obliged to check his / her validity and correspondence of the quantity of the mentioned drugs, substances and precursors to the information given in the accompanying documents, their correct marking and packaging and to sign the corresponding documents.

The transportation of narcotic drugs, psychotropic substances and precursors by economic entities is carried out on the basis of the goods waybill accompanied by the responsible person (representative of the 
consignor or consignee, who is familiar with the properties of these agents, substances and precursors and rules of safe handling).

The responsibilities of the responsible person include:

- escort and protection of narcotics, psychotropic substances and precursors during their transportation to their destination;

- instructing the driver who carries out narcotics transportation drugs, psychotropic substances and precursors;

- inspection of the motor vehicle and provision in case of need for its repair;

- verification of the correct labeling and packaging of drugs, psychotropic substances and precursors and their acceptance;

- monitoring of loading and fixing of cargo;

- transfer of narcotics, psychotropic substances and precursors upon arrival at the destination;

- personal security.

The transportation of precursors included in list $\mathrm{N} 2$ of table IV of the list, including non-resident carriers, is carried out in accordance with the established requirements of the Ministry of Internal Affairs.

\section{CONCLUSIONS}

Knowledge of the peculiarities of the activities related to the circulation of narcotic, psychotropic substances, their analogues and precursors in the territory of Ukraine will allow to objectively observe the due observance of the legislation by economic entities and persons directly involved in committing certain actions related to narcotic drugs, psychotropic substances, their analogues and precursors in the territory of Ukraine.

\section{SUMMARY}

The paper outlines the requirements to be met by certain types of business activities related to the circulation of narcotic, psychotropic substances, their analogues and precursors in Ukraine. It is established that manufacture of medicines, wholesale and retail trade in medicines, import of medicines; cultivation of plants included in Table I of the List of narcotic drugs, psychotropic substances and precursors, development, production, production, storage, transportation, purchase, sale (vacation), import to the territory of Ukraine, export from the territory of Ukraine, use, destruction of narcotic drugs are subject to licensing. This paper examines the licensing procedure and describes the procedure for issuing permits for the use of facilities and premises, the removal of funds from 
Ukraine for activities related to drug trafficking. The key stages of licensing and the mechanism of its implementation are described. The peculiarities of storage of narcotic drugs, psychotropic substances and precursors removed from illicit trafficking are investigated. The analysis of the legislative support of the order of transportation of narcotic drugs, psychotropic substances and precursors in the territory of Ukraine is conducted. The responsibilities of the responsible persons for the transportation procedure are established.

\section{REFERENCES}

1. Закон України “Про ліцензування видів господарської діяльності” від 02.03.2015 № 222-VIII (у ред. від 05.07.2017). [Електронний ресурс]: Режим доступу: http://zakon2.rada.gov.ua/ laws/show/222-19.

2. Закон України "Про лікарські засоби" від 04.04.1996 № 123/96-ВР (у редакції від 19.06.2016): [Електронний pecypc]. - Режим доступу: http://zakon0.rada.gov.ua/laws/show/ 123/96-вр.

3. Невеликі, великі та особливо великі розміри наркотичних засобів, що знаходяться у незаконному обігу / Таблиця 1 / Затверджена наказом Міністерства охорони здоров'я України 01.08.2000 N 188 (у редакції 19.06.2015): [Електронний ресурс]. Режим доступу: http://zakon2.rada.gov.ua/laws/show/z0512-00.

4. Закон України "Про наркотичні засоби, психотропні речовини і прекурсори” від 15.02.1995№ 60/95-ВР (у редакції 28.12.2015): [Електронний ресурс]. - Режим доступу: http://zakon2.rada.gov.ua/laws/show/60/95-вр.

5. Кодекс України про адміністративні правопорушення (статті 1 - 212-21) від 07.12.1984 № 8073-Х (у редакції 16.04.2017): [Електронний ресурс]. - Режим доступу: http://zakon2.rada.gov.ua/ laws/show/80731-10;

6. Постанова Кабінету Міністрів України “Деякі питання видачі дозволу на використання об'єктів і приміщень, призначених для провадження діяльності, пов'язаної 3 обігом наркотичних засобів, психотропних речовин і прекурсорів” від 13.04.2011 № 469 (у ред. від 11.04.2017). [Електронний ресурс]. - Режим доступу: http://zakon2.rada.gov.ua/ laws/show/469-2011-п.

7. Закон України "Про Національну поліцію” від 2.07.2015 р. № 580-19 (в ред. від 12.07.2017р.). [Електронний ресурс]. - Режим доступу: http://zakon2.rada.gov.ua/laws/show/580-19/page; 
8. Постанова Кабінету Міністрів України “Про затвердження форми заяви на одержання суб'єктом господарювання або уповноваженою ним собою документів дозвільного характеру" від 7.12 .2005 p. N 1176 (в ред. від 11.02.2015 - втратив силу). [Електронний ресурс]. - Режим доступу: http://zakon2.rada.gov.ua/ laws/show/ru/1176-2005-п.

9. Постанова Кабінету Міністрів України “Порядок видачі дозволів на право ввезення на територію України, вивезення 3 території України або транзиту через територію України наркотичних засобів, психотропних речовин i прекурсорів" від 03.02.1997 № 146. [Електронний ресурс]. - Режим доступу: http://zakon2.rada.gov.ua/ laws/show/146-97-п.

10. Закон України "Про дозвільну систему у сфері господарської діяльності” від 06.09.2005 № 2806-IV (у ред. від 05.07.2017). [Електронний ресурс]. - Режим доступу: http://zakon2.rada.gov.ua/laws/show/2806-15.

11. Постанова Кабінету Міністрів України "Порядок перевезення наркотичних засобів, психотропних речовин i прекурсорів на території України та оформлення необхідних документів” від 17.04.2008 № 366 (у ред. від 18.03.2016). [Електронний ресурс]. - Режим доступу: http://zakon2.rada.gov.ua/ laws/show/366-2008-п.

12. Закон України "Про оперативно-розшукову діяльність" від 18.02.1992 № 2135-XII (у редакції 12.04.2017): [Електронний peсурс]. - Режим доступу: http://zakon3.rada.gov.ua/laws/show/ 2135-12.

13. Постанова Кабінету Міністрів України "Правила дорожнього руху” від 10 жовтня 2001 p. № 1306 (у ред. від 05.04.2017). [Електронний ресурс]. - Режим доступу: http://zakon2.rada.gov.ua/laws/show/1306-2001-п.

\section{Information about the author: Sokolenko O. L.,} Doctor of Laws, Professor, Dean of the Law Faculty, Oles Honchar Dnipro National University 72, Gagarin Ave., Dnipro, 49000, Ukraine 